の結果安定なエマルジョンとなると考えることができる。

\section{4 粘度数}

極限粘度数により，分散状態の相違がほぼ明らかとなった。そ のような各相間の相違だケでなく，粘度は全体に連続的な変化を 示すものとしてとらえることも可能である。それは極限的性質で なく，ある濃度に打ける粒子のすべての性質を含めて示すことに なるからである。

$2 \times 10^{-2} \mathrm{~g} / \mathrm{m} l$ 水溶液の濃度に打ける粘度数を各测定点につい てプロットして，等価な粘度数を結んでみると，図 8 のような結 果となる。粘度数はほぼ相変化にそっていて，䛒点曲線付近が最 む著しい変化を示している。さらに詳しくみると, 粘度数の最大
位置は $m-\mathrm{X}$ の割合の少ない領域で可溶化領域に存在し， $m-\mathbf{X}$ の割合の多い領域で，鲠点より若干高い白濁領域にある。なお， PNE だけの溶液では晨点以上に打いて分離が速いので, 図 8 K は概略値を示した。

可溶化領域の大部分拈よび乳化領域（I）は五とんど違いがな く，極限粘度数で示したように粘度的には同一である。

終りに本研究を行なうにあたり，御指導いただいた横浜国立大 学工学部集田耕三教授に，また原稿作成にあたり，御指導いたた いた宇部興産（株）枚方樹脂研究所星野貞夫博士に感謝いたしま す。

\title{
薄膜分別溶解法によるポリ酢酸ビニルの重合度分布の測定
}

\author{
(昭 和 42 年 8 月 9 日 受理)
}

$$
\text { 箱 崎 順 一*1 }
$$

\footnotetext{
㵶維用ボリビニルアルコールの重合度分布の測定に，迅速法としてアセチル化により合成したポリ酢酸ビニルを用いて薄膜を作 り，それに対して分別抽出溶解法を適用した。この方法について次のことを検討した。すなわち再現性は抽出時間，抽出溶媒組成 の変化により，得られる分布の信頼性は重合度分布既知の低重合率のモデルポリマーについての実測值と理論分布関数との比較, さらに分離能は重合度分布が既知で異なる二つの区分の混合物の分別を行ない，計算值との比較によりそれぞれ満足すべき結果を 得た。

PVA 粉末を $60^{\circ} \mathrm{C}$ の温水で 20 時閒処理を行ない, その前後の重合度分布の測定によって，異種結合が多い低重合度分子のみ が溶出することを明らかにした。さらに分別区分やいくつかの市販 PVA の重合度分布を本法によって比較し，各種平均重合度， 多分散性の尺度について議論を行なった。
}

\section{1 緒言}

合成繊維としてのビニロンの原料であるポリビニルアルコール (PVA) は結晶性高分子であるために，重合度分布の正しい測定 は困難であるが, PVAをアセチル化してポり酢酸ビニル(PVAc) にすると、いくつかの分別法が適用できるようになる。しかし， 分別沈殿法は，いわゆる “すそ効果” のため分離能が悪くしかも 時間的にも能率がよくない。沈殿濁度滴定法では, 濁りとしてこ の方法の原理を満足する良好な沈殿を作る溶媒-非溶媒系を見い 出すことができず，PVA を他の誘導体であるポリビニルホルマ ールや，アセタールなどにしてもいずれも成功することができな かった。一方カラム法では, PVAc の 2 次転移温度が低いため, 付着させた担体同志が粘着して塊りを生じたりして再現性ある結 果を得ることができなかった。

著者は, Fuchs')，Beresniewicz ${ }^{2)}$ らの用いた薄膜分別溶解法 をPVA をアセチル化した PVAc に適用した結果，迅速でかつ 信頼珄のある簡便な手法であることを明らかにした。Fuchs 以来 この方法に対し，いくつかの疑問点すなわち, 得られた分布の信

*1 Jun-ichi HAKOZAKI 三菱レイヨン(株) 研究部 : 東京都 中央区京橋, 現在, 日本ュニカー(株)川崎工業所 : 川崎市 浮島町.

1) O. Fuchs, Makromol. Chem., 5, 245, 249 (1951).

2) A. Bẹreșniẹwiçz, J. Polỵmer Sçi., 3̧5, 321 (1959).
頼性がとぼしい，膨潤フィルムと溶液の間の熱力学的平衡に達す るまでの時間が長い, 分子量の分離能が悪いなどが提出されてい た。本報は, 緘維用ビニロン原料の PVA について, この方法の 再現性 重合度の分離能，抽出溶解時間など基本的な点について 検討し,さらに, 重合度分布関数既知のモデル PVAc について 理論関数との比較による本法の妥当性, いくつかの市眅 PVA お よび温水処理 PVA の重合度分布の比較を行なったものである。

\section{2 実験}

$2 \cdot 1$ 試 料

測定に用いた PVA および PVAc の性状は次のようなるので ある。

試料 A-0：N社製再ヶン化 PVAで重合度分布が広い未分別試 料。平均重合度 $\left(\bar{P}_{\mathrm{AC}}\right) 1270$ 。

A-1：A-0 を水ーノルマルプロパノール系で 11 区分に分 別したものの第 4 区分。 $\bar{P}_{\mathrm{AC}} 1540$ 。

A-2：A-0. を粉末状のまま $60^{\circ} \mathrm{C}$ 温水中に浸してときどき かきまぜながら 20 時間処理した後，口過し，残分 をメタノールで洗浄乾燥したもの。この処理で容出 分は $22.7 \%$ で残分の $\bar{P}_{\mathrm{AC}}$ は 1550 , 溶出分の $\bar{P}_{\mathrm{AC}}$ 435 であった。

試料 B：N社製で試料 $\mathrm{A}$ より重合度分布が狭いといわれてい るもので末分別。 $\bar{P}_{\mathrm{AC}} 1260$ 。 
試料 C : アゾビスイソブチロニトリル $0.05 \%, 60^{\circ} \mathrm{C}$ メ 一ル 24\% の溶液重合による PVAc で重合率 $15 \%$ の未分別。 $\bar{P}_{\mathrm{AC}} 2520$ 。

試料 D-1 : アゾビスイソブチロニトリル $0.02 \%, 58^{\circ} \mathrm{C}$ メタノ ニル 20\% の溶液重合による PVAc で重合率 69\%。 アセトンー水系で 9 区分に分別沈股したものの中の 1 区分。 $\bar{P}_{\mathrm{AC}} 3980$ 。

D-2：試料 D-1 と同じで $\bar{P}_{\mathrm{AC}} 770$ 。

試料 $\mathrm{E} ： \mathrm{~S}$ 社製末分別で $\bar{P}_{\mathrm{AC}} 1300$ 。

試料 F : D 社製未分別。 $\bar{P}_{\mathrm{AC}} 1920$ 。

これらの試料の $\bar{P}_{\mathrm{AC}}$ はすべてアセチル化後の PVAcについ てメチルエチルエチルケトン $(\mathrm{MEK})$ 溶液 $25^{\circ} \mathrm{C}$ で $[\eta]=4.20 \times$ $M_{\mathrm{w}}{ }^{0.62}$ 9) より求めた。

\section{2 アセチル化反応}

メタノールで精製した PVA にピリジン，無水酢酸を加兄約 $100^{\circ} \mathrm{C}$ ではげしくかきまぜながら 5 時間反応すると均一溶夜とな り PVAc が生成する。これを沸騰蒸留水中に注き，ときどき水 を取り換えて十分洗浄したあと $80^{\circ} \mathrm{C}$ 真空乾燥を数日行なった。 アセテル化は 99\% 以上行なわれ, 重合度低下がないことを別に 確かめた。

\section{$2 \cdot 3$ 溶液粘度測定法}

初めの各試料の溶液粘度測定は, Ubbelohde 希釈型粘度計を用 いた。一方分別溶解によって得た区分の粘度測定は, Ubbelohde 型を改良した迅速粘度計で各区分一濃度で行なった。この粘度計 は, 一般の Ubbelohde 型粘度計の液留の部分をスリ合せによっ て交換可能にしたもので,この部分を必要量だけ準備しておけば, 䟴度あるいは, 種類の異なる測定液を迅速に連続的に测定できる。 分別区分は，約 $0.3 \mathrm{~g} / 100 \mathrm{ml}$ の濃度になるよ し，低分子量区分から順次液留を取り換えながら測定した。測定 温度 $25^{\circ} \mathrm{C}$ で MEK 約 $1 \mathrm{ml}$ の流下時間は 166 秒で, 運動エネ ルギーの補正は小さいので必要なく, 各区分の測定前に 1 回洗い 棄てて測定するが，液は $5 \mathrm{~m} l$ あれば十分である。

極限粘度 [ $\eta]$ は 1 濃度の相対粘度 $\eta_{\mathrm{r}}$ から Baker 式を用い て求めた。すなわち

$$
[\eta]=a\left(\eta_{\mathrm{r}}{ }^{1 / a}-1\right) / c
$$

ここで $a=3$ であることを Huggins の $k^{\prime}$ が PVAcについて $0.3 \sim 0.35$ になることから $a=1 /\left(1-2 k^{\prime}\right)$ に従って確認した。重

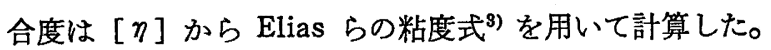

\section{4 薄膜分別溶解法}

PVAc の薄膜を付着させる材料として，アルミニウム箔，銅䈃 をまず検討したが，分別中にはがれ落らる欠楩がみいだされたの で, 150 mesh 以上の細かいステンレス金網を用いることにした。 目の荒い網は，PVAc の厚みが均一にならないなど，付着に手間 どるが， 325 mesh を用いた所，良好な薄膜を付着させることが できた。金網は幅 $3 \mathrm{~cm}$, 長さ $50 \mathrm{~cm}$ に切り,クロム硫酸で十分 洗浄して用いた。PVAcは, 約 7〜8\% タタノール溶液にし, こ の中に数回金網を漬けることによって付着させた後, 十分乾燥を 行なった。一試料の分別には，9本の金網を用いたが付着量は約 1 1.5 g の重量であった。分別器は, Beresniewicz や Fuchs の用いた容器とほぼ同じもので, 容量 $300 \mathrm{ml}$, 底部に 3 号ガラス フィルターをつけ，2重壁のジャケットに恒温水を通して温度調

3) F.Patat, H.G.Elias, Makromol.Chem., 14, 40(1959).
節を行ないつつ, 振とう器によって往復運動をさせて抽出した。 抽出夜は，酢酸エチル (AcOEt) と石油エーテルの組み 合むせで 順次その比率をか充溶解力を増加させて行くが，-1回の抽出に用 いる量は $200 \mathrm{ml}$ で振と 5 は，ストローク $20 \mathrm{~cm}, 1$ 分当り約 120 回往復させた。一定時間抽出後, 抽出液を吸引口過によって, 他の容器に移し, 蒸発乾固, 乾燥後重量を秤量し, 約 $0.3 \%$ の溇 度になるよ5に MEK を用いて溶液を作り粘度法により重合度を 測定した。

\section{$2 \cdot 5$ 分別沈殿法}

容量 $1 l$ の底部に約 $10 \mathrm{ml}$ の突起をつけた カキマゼ器つきの 三つロフラスコを用い, アセトンー水系, $23^{\circ} \mathrm{C}$ で分別沈殿を行な った。沈殿相の分離には，もら一つのフラスコを用意し，希溥液 相をポリェチレンパイプで移して行なった。

\section{3 実験結果と考察}

\section{1 再現性の検討}

分別抽出法の再現性を検討するために，A-0 の PVA につい て，酢酸化反応からまったく独立に 2 回の分別を行ない，その結 果を比較した。条件は,アセチル化反応, 製膜法は同一であるが, 抽出液組成は $44 \sim 58.5 \%$ と 48〜 59\% (AcOEt として)，抽出時 間は各区分当り 10 分と 15 分, 抽出温度 $25.5^{\circ} \mathrm{C}$ を用いた。分 別結果の一例を表 1 に示した。

末ったく別々に行なった二つの分別操作の結果について，抽出

表 1 A-0 の分別抽出結果

\begin{tabular}{|c|c|c|c|c|c|}
\hline 区 分 & $\underset{(\%)}{\operatorname{AcOEt}}$ & 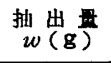 & $\begin{array}{l}\text { 执出分事 } \\
w_{i}(\%)\end{array}$ & 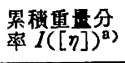 & $\begin{array}{c}{[\eta]} \\
(100 \mathrm{ml} / \mathrm{g})\end{array}$ \\
\hline 1 & 48 & 0.1240 & 9.52 & 4.76 & 0.110 \\
\hline 2 & 50 & 0.0768 & 5.89 & 12.47 & 0.163 \\
\hline 3 & 52 & 0.0761 & 5.83 & 18.13 & 0.253 \\
\hline 4 & 53 & 0.0725 & 5.56 & 24.02 & 0.293 \\
\hline 5 & 54 & 0.0762 & 5.85 & 29.73 & 0.333 \\
\hline 6 & 54.5 & 0.0652 & 5.00 & 35.15 & 0.369 \\
\hline 7 & 55 & 0.0586 & 4.48 & 39.87 & 0.418 \\
\hline 8 & 55.5 & 0.0723 & 5.53 & 44.90 & 0.490 \\
\hline 9 & 56 & 0.0811 & 6.20 & 50.76 & 0.518 \\
\hline 10 & 56.5 & 0.0890 & 6.91 & 57.32 & 0.593 \\
\hline 11 & 57 & 0.1055 & 8.10 & 64.82 & 0.647 \\
\hline 12 & 57.5 & 0.1148 & 8.81 & 73. 28 & 0.788 \\
\hline 13 & 58 & 0.1209 & 9.27 & 82.32 & 0.883 \\
\hline 14 & 58.5 & 0.0855 & 6.54 & 90.22 & 1.091 \\
\hline 15 & 60 & $\begin{array}{c}0.0850 \\
w=1.30 .35\end{array}$ & 6.51 & 96.75 & 1.379 \\
\hline
\end{tabular}

a) $I([\eta])=1 / 2 w_{j}+\sum_{i=1}^{i} w_{l}$.

b) 回收部 $98.5 \%$.

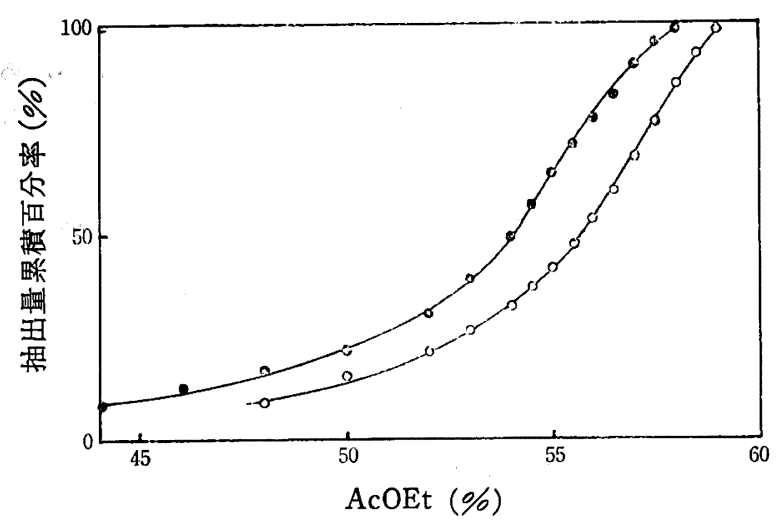

図 1 抽出液組成と抽出量累積百分率の関係

-○-：1回目，一○一：2靣目 


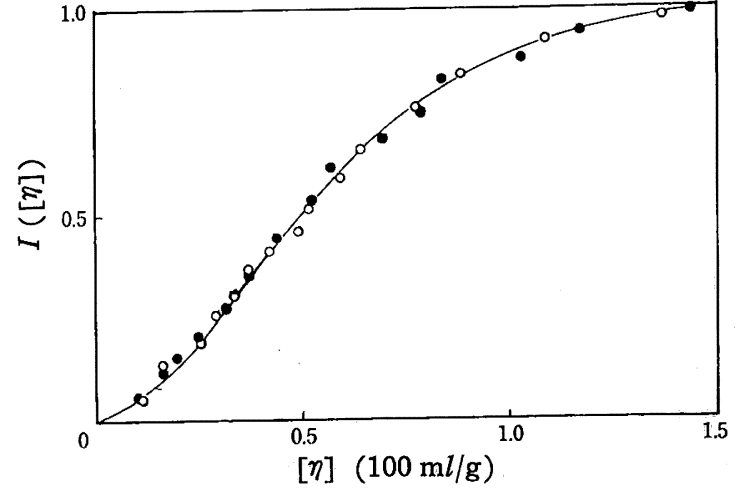

図 2 抽出液組成の異なる别々の分別操作によって得ら れた $[\eta]$ の積分分布曲線

一○： 1 回目, 一O-：2回目

夜組成と累積重量百分率との関係を図 1 に示した。抽出液組成と 抽出時間の相違によって抽出重量は異なっているが，各区分の

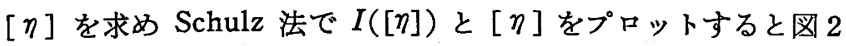
に示すように非常に良い一致をみ，再現性は良好であることがわ かった。

Tung4) は分布曲線を数式化し指数分布関数として表現したの をこの場合に適用した。すすなわち積分分布曲線 $I(x)$ は (2) 式 で示される。

$$
I(x)=1-\exp \left(-a x^{b}\right)
$$

ここで $x$ は重合度, 分子量または極限粘度で, $a, b$ は定数であ る。（2）式を変形し両辺の対数をとると（3）式で表わすことが できるから

$$
\log \left[\log \left\{\frac{1}{1-I(x)}\right\}\right]=\log \left(a \log ^{-} e\right)+b \log x
$$

$\log \cdot \log \{1 / 1-I(x)\}$ と $\log x$ との関係を求めると直線関係が求 まり，その勾配と縦座標から $a$ と $b$ が得られる。微分分布関数は (3)式を微分することによって導かれる（4) 式から求められる。

$$
w(x)=\frac{\mathrm{d} I(x)}{\mathrm{d} x}=a \cdot b x^{b-1} \exp \left(-a x^{b}\right)
$$

試料 A-0 について再現性の検討を行なった 2 回のデータを

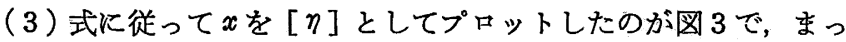
たく一致した 1 本の直線が得られた。この直線から $a=2.10, . b=$ 1.65 が求められたが, この值を（3），(4) 式に代入し数值計算 を行ならと図 4 が得られ，あわせて示した Schulz のプロットと まったく一致することがわかった。

\section{$3 \cdot 2$ 重合度分布が既知のモテルボリマーの分別}

薄膜分別溶解法の信頼性, 分離能など疑問とされていた点を明 らかにするために重合度分布が既知のモデルポリマーについて測 定しその結果と理論からの值とを比較した。

一般に PVAc の低重合率ポリマーは分枝効果を無視すること ができて，その分子量分布は $M \exp (-M)$ 型であることが，松 本により明らかにされている5)。ここで，この条件をできるだけ 满足する試料を重合し試料Cとした。Flory は，この分布関数が Most probable 分布として（5）式で示した。

$$
w(P)=h^{2} P \exp \{-h P\}
$$

ここで $1 / h=\bar{P}_{\mathrm{n}}$ (数平均重合度) である。試料 Cは $[\eta]=0.827$

4) L. H. Tung, J. Polymer Sci., 20, 495 (1956).

5）松本昌一, 高分子化学, 10, 32 (1953).

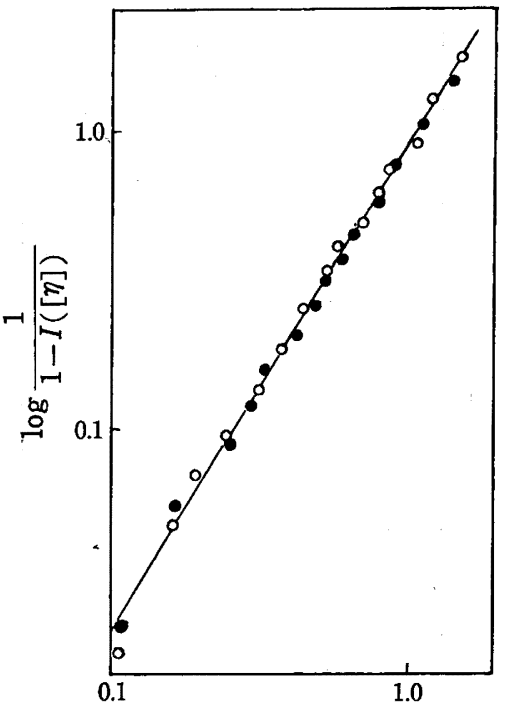

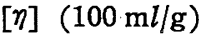

図 3 試料 A-0 の Tung 式によるプロット

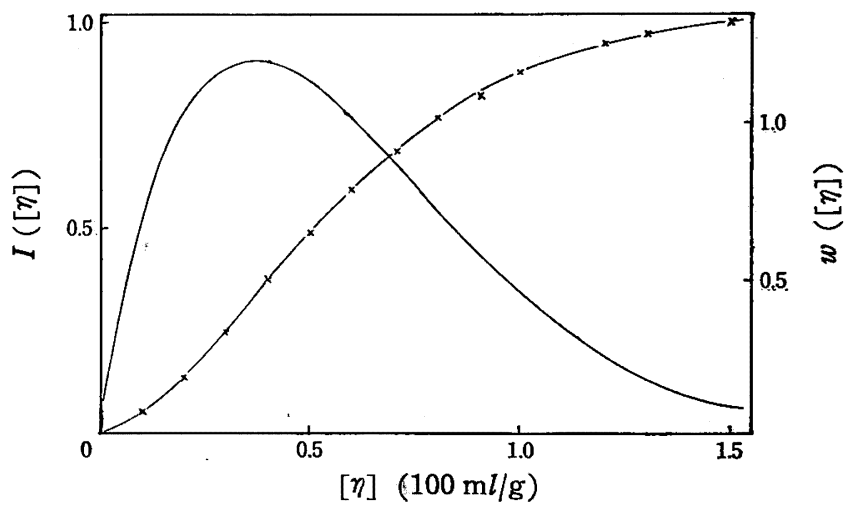

図 4 A-0 の[ $\eta]$ の積分および微分分布曲線

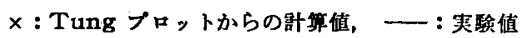

であるから Elias ${ }^{9)}$ 式から $\bar{P}_{\mathrm{v}}=2390$ となる。一方 $\bar{P}_{\mathrm{n}}$ と $\bar{P}_{\mathrm{v}}$ との間には (6) 式が成立するから $\bar{P}_{\mathrm{v}}$ から $\bar{P}_{\mathrm{n}}$ が求められる。

$$
\bar{P}_{\mathrm{n}}: \bar{P}_{\mathrm{v}}=1:[(1+\alpha) \Gamma(1+\alpha)]^{1 / \alpha}
$$

ここで $\alpha$ は $[\eta]=K M^{\alpha}$ から 0.62 であるので $\bar{P}_{\mathrm{n}}=1310, h=7.63$ $\times 10^{-4}$ となる。また（5）式を積分すると，（7）式の積分分布 関数が得られる。

$$
I(P)=1-e^{-h P}(h P+1)
$$

試料Cは重合率が $15 \%$ で理論分布をもつ試料として適切でな いかもしれないが，実際に分別を行ない比較した。抽出時間 15 分, 区分数 12 で Tung 式によりプロットすると $P=2500$ で折 れ曲がる 2 本の直線が得られ(図 5 )，P>2500で $a=9.56 \times 10^{-5}$ ， $b=1.16, P<2500$ で $a=3.26 \times 10^{-6}, b=1.60$ であった。これら の值を（2），(4) 式に代入し，積分および微分曲線を求め (5), （7）式の理論分布と比較し図 6 に示した。

この曲線は理論分布と非常によく一致しているが, 一部でわず か偏りがみられるのは, 重合率がいくぶん高かったためと考えら れる。しかし，このよらなかなりよい一致は薄膜分別溶解法が PVAc に対し正しい分布関数を求める手段であるといえる。

Tung の（2）式から $a, b$ を用いて $\Gamma$ 関数により（8）式に 従い $\bar{P}_{\mathrm{n}}, \bar{P}_{\mathrm{w}} ; \bar{P}_{\mathrm{z}}$ を容易に計算することができる。 


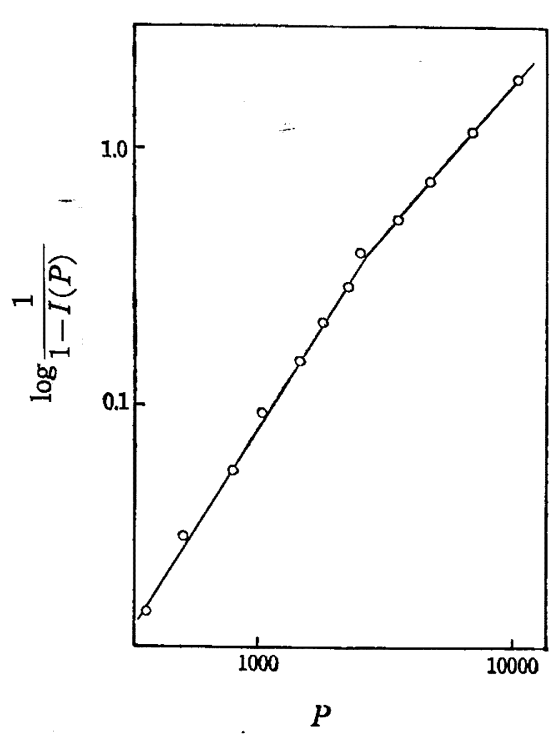

図 5 試料Cの Tung 式によるプロット

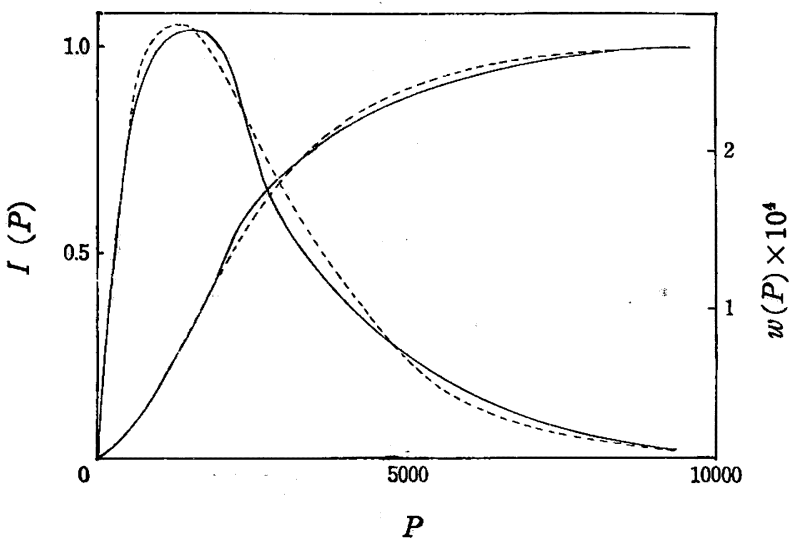

図 6 試料 Cの理論分布と実験值との比較 --- : 理論分布，一：実験値

$$
\left.\begin{array}{l}
\bar{P}_{\mathrm{n}}=\left\{a^{1 / b} \Gamma(1-1 / b)\right\}^{-1} \\
\bar{P}_{\mathrm{w}}=a^{-1 / b} \Gamma(1+1 / b) \\
\bar{P}_{\mathrm{z}}=a^{-1 / b} \Gamma(1+1 / b) / \Gamma(1+1 / b)
\end{array}\right\}
$$

ただし（8）式は $a ， b$ が一つの值をるつ分布でないと計算でき ないので, 試料 A-0 の場合は，（8）式により計算したが，Cの 場合は分布曲線の図上解析によって求め $\bar{P}_{\mathrm{w}} / \bar{P}_{\mathrm{n}}$ を比較した（表 2 )。

理論值の $\bar{P}_{\mathrm{w}} / \bar{P}_{\mathrm{n}}=2$ に対し, Cでは 2.2 とやや大きい值にな っているが，この差はすでに述べたよ5に重合率がやや大きかっ たために連鎖移動で停止反応が起こり分枝が多くなったためと思 われる。このことはCの PVAc をケン化してできた PVA の $\bar{P}$ が 1750 と低下し分枝のケタール結合が加水分解されていること からす理解できる。一般に PVAc では低重合率の段階では直鎖

\begin{tabular}{|c|c|c|c|c|c|}
\hline 試 料 & {$[\eta]$} & $\bar{P}_{\mathrm{v}}{ }^{a)}$ & $\bar{P}_{\mathrm{w}}$ & $\bar{P}_{\mathbf{n}}$ & $\bar{P}_{\mathrm{w}} / \bar{P}_{\mathrm{n}}$ \\
\hline 理 螎 值 & 0.827 & 2390 & 2620 & 1310 & 2.00 \\
\hline C & 0.827 & 2390 & 2830 & 1270 & 2.23 \\
\hline A-0 & 0.570 & 1300 & 1480 & 390 & 2.79 \\
\hline
\end{tabular}
高分子の生成が主に起こるが，重合率の上昇にともない2 次的重

表 2 各試料の $\bar{P}_{\mathrm{w}} / \bar{P}_{\mathrm{n}}$

a) Elias 式 ${ }^{3)}[\eta]=4.20 \times 10^{-4} \bar{M}_{\mathrm{v}}{ }^{0.82}$ より計算した.

6）中島章夫，桜田一郎，高分子化学，11，110 (1954)
合（橋かけ反応）が起こり易くなり，その確率は $\bar{P}_{\mathrm{w}}$ に比例し， さらに重合度分布も広くなることが知られているが6)，表 2 の $\bar{P}_{\mathrm{w}}$ の理論值と央測值のくい違いも，これに起因するものと考え られる。

\section{$3 \cdot 3$ 二つの分別区分の混合物の分離}

重合度の分離能を明らかにするために平均重合度の異なる二つ の分別区分の混合物を作り，分別溶解法を試みた。この方法を行 な5前に比較のために, アセトンー水系で分別沈殿を行なった。 試料は D-1 $(\bar{P}=3980)$ と D-2 $(\bar{P}=770)$ の 2 区分の等量混合 物で, $2 \cdot 5$ に示した分別沈殿法に従って求めた積分および微分曲 線が図 7 である。低重合度区分 D-2 では $\bar{P}_{\mathrm{v}}$ と $w(P)$ の最大值 が一致しているが，高重合度区分 D-1 では一致していない。こ のことは D-1 区分では，かなり低重合度分子種をふくんだ不均 一な区分の分別しか行なわれていないためと思われる。

次に分別溶解法によって各区分の分布を個々に測定した。抽出 時間は D-1 が 20 分，D-2 が 15 分で得られた積分分布曲線を

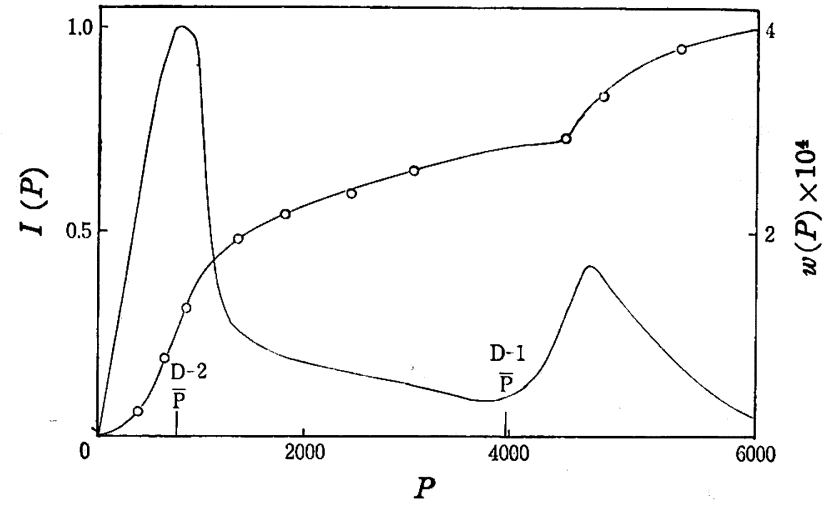

図 7 試料 D-1 と D-2 の等量混合物 の分別沈股法に よる重合度分布曲線

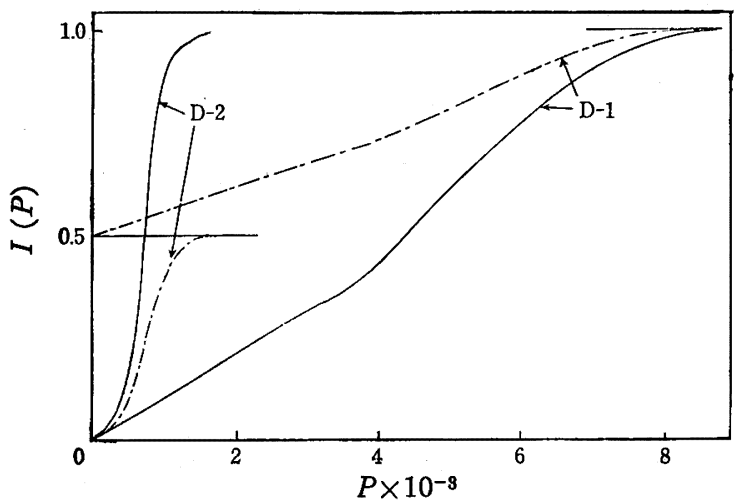

図 8 試料 D-1，D-2 の分別溶解法による積分分布曲線 — : $I(P),---: 1 / 2 I(P)$

同一スケールで書き，その $1 / 2$ (等量混合物であるから）に相当 する曲線も合わ岲て因 8 に示した。このように分別区分の重合度 分布は D-2 ではかなり狭く，（8）式従って計算すると $\bar{P}_{\mathrm{n}}=$ $600, \bar{P}_{\mathrm{w}}=725$ で $\bar{P}_{\mathrm{w}} / \bar{P}_{\mathrm{n}}=1.21$ であった。しかし高重合度区分 の D-1 は非常に広く低重合度成分の分率も高くて明らかにすそ 効果が大きいことがわかる。図 9 は D-1 と D-2 の等量混合物に ついて図 8 の合成分布曲線，分別沈殿法の測定值に加えて実際に この試料の分別溶解法による测定結果を積分分布曲線で示したも のである。分別溶解法の二つの結果は非常によい一致をみている 


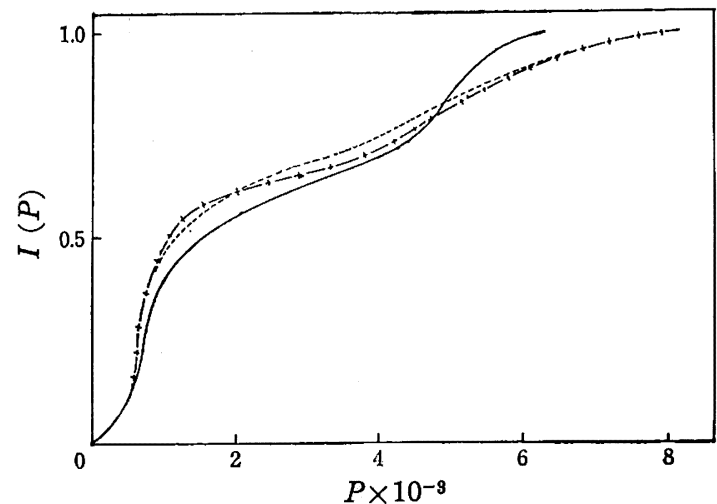

図 $9 \mathrm{D}-1$ と D-2 の等量混合物の分別沈殿および分別 溶解法による積分分布曲線の比較

- : 分別沈殿法, --- : 分別溶解法, -+- : 図 8 の合成曲線

が，逐次分別沈段法は，見かけ上狭い分布を示し，特に高重合度 部分で低重合度成分を含んで分別された“すそ効果”が明らかに 認められる。これに対し薄膜溶解法は重合度の低い区分から分別 が行なわれてゆくために “すと効果” は考光られない。このこと は図 9 で低重合度区分の分率が分別沈殷法に比し高いこと，より 高重合度区分まで分別によって得られていること，さらに二つの 独立に得られた分布曲線の合成曲線と混合物の実測分布曲線が非 常に良い一致を示していることなどからわかる。

以上の結果から Patat ら゙)もいっている抽出時間が短いために 熱力学的に準平衡状態で分別が行なかれ，高分子量分子種に対し ては分別溶解法は適用できないという説に対して，ここで検討し た重合度範囲すなわち 10000 程度まではこの方法で問題ないと考 えてよいだろう。また分別沈股法に比しすそ効果もなく，分離能 にすぐれ得られた結果の信頼性も高く，試料が少ないこと，測定 時間が短く再現性のあることから，日常分析法としても適用でき る手法といってよい。

3.4 PVA の温水溶解処理による重合度分布の変化

一般に PVA の工業製品は粉末状で温水では膨潤し, 沸騰水で

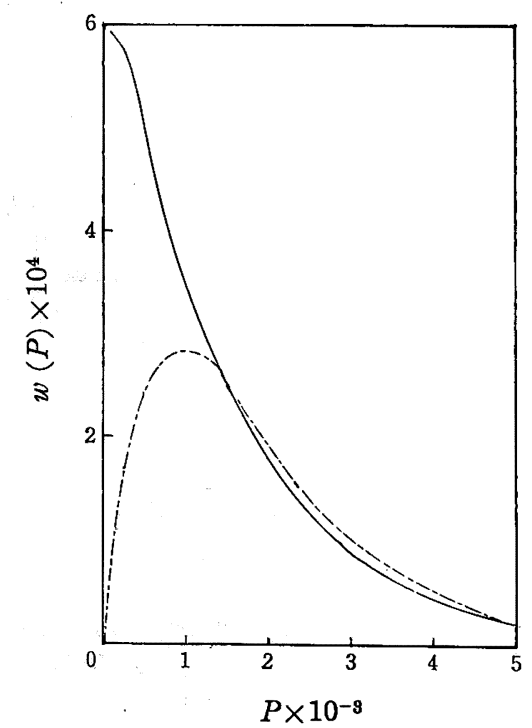

因 $10 \mathrm{~A}-0$ の温水処理前と後の微分分布曲線の比較 — : A-0, - - : A-2

7) F. Patat, K. Damaschke, Makromol. Chem., 33, 131 (1959)
は完全に溶解するが，熱処理によって温水の膨潤挙動は大きく異 なってくる。これは熱処理により結晶化が進み水に対する溶解度 が小さくなるためであるが，㵶維用 PVA は多かれ少なかれ熱処 理されて市肘されている。結晶化度の目安として皮膜膨潤度が一 般に用いられて扣り，その測定のさい低分子量成分が溶出するこ とが観察されている。ここでは粉末状 PVA から低分子量成分を 除去するために試料 A-0 を2.1 で述べた方法で $60^{\circ} \mathrm{C}$ の温水処 理を行ない試料 A-2 を得た。各区分の $\bar{P}_{\mathbf{v}}$ は原試料が 1270 , 残分 (A-2) が 1550, 溶出分 435 で溶出率は 22.7 であり, 明 らかに低分子量成分がかなりの量取り除かれたことがわかった。 溶出分除去前と後の重合度分布を分別溶解法で測定し， A-0 を $100 \% ， A-2$ を 77.3\% として微分分布曲線を比較したのが図 10 で，A-0 で分率の大きい低重合度成分が，かなり除去されてい るにもかかわらず，重合度が 1500 以上の高分子量成分はまった

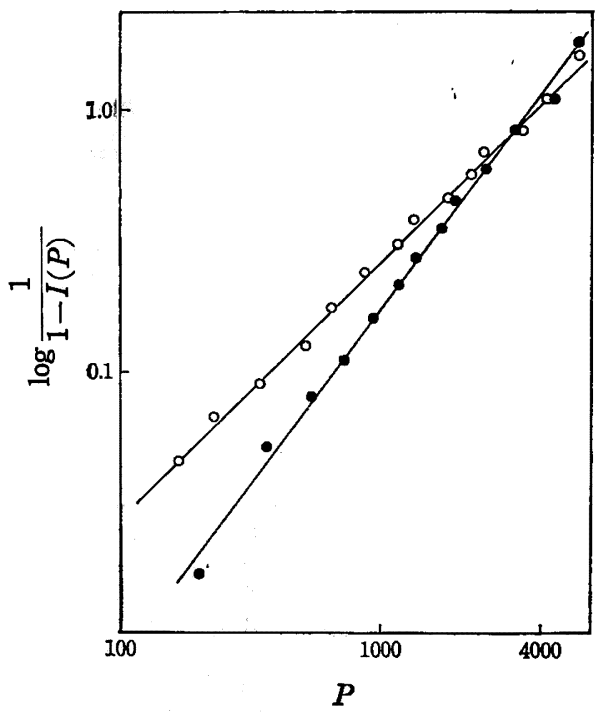

因 11 A-0 の温水処理前と後の実験值の Tung 式によ るプロット $-\mathrm{O}-: \mathrm{A}-0,-\mathbf{O}-\mathbf{A - 2}$

く温水により溶出されず残存していることは興味あることであ る。な拉，この分布曲線は Tung の方法で解析し，全重合度領 域にわたって 1 本の直線すなわち（3）式が成立し（図 11），得 られた $a ｂ$ より（4）式に従って計算によって求めたものであ る。A-0 と A-2 について（8）式より求めた各平均重合度，お よび不均一性を示すパラメーターを表 3 にまとな。ここで U, $\delta, \sigma_{\mathrm{w}}$ (標準偏差), $\nu_{\mathrm{w}}$ (歪み度) は以下に示す意義をもつパラメ ーターである。

$$
\begin{aligned}
& \mathrm{U}=\left(\bar{P}_{\mathrm{w}} / \bar{P}_{\mathrm{n}}\right)-1 \\
& \delta=\left\{\left(\bar{P}_{\mathrm{z}}-\bar{P}_{\mathrm{w}}\right) / \bar{P}_{\mathrm{w}}\right\}^{1 / 2} \\
& \sigma_{\mathrm{w}}=\left\{\bar{P}_{\mathrm{w}} \cdot \bar{P}_{\mathrm{z}}-\left(\bar{P}_{\mathrm{w}}\right)^{2}\right\}^{1 / 2} \\
& \nu_{\mathrm{w}}=\bar{P}_{\mathrm{w}}-\left(\bar{P}_{\mathrm{c}}\right)_{\mathrm{w}}
\end{aligned}
$$

表 3 平均重合度と重合度の不均一性パラメーター

\begin{tabular}{cccccccrr} 
武料 & $\bar{P}_{\mathrm{v}}$ & $\bar{P}_{\mathrm{n}}$ & $\bar{P}_{\mathrm{w}}$ & $\bar{P}_{\mathrm{z}}$ & $\mathrm{U}$ & \multicolumn{1}{c}{$\boldsymbol{\delta}$} & \multicolumn{1}{c}{$\boldsymbol{\sigma}_{\mathrm{w}}{ }_{12}$} & \multicolumn{1}{c}{$\nu_{\mathrm{w}}$} \\
\hline A-0 & 1270 & 330 & 1510 & 2960 & 2.97 & 0.98 & 14.8 & 390 \\
A-2 & 1550 & 580 & 1860 & 2780 & 2.20 & 0.68 & 13.0 & 320 \\
A-1 & 1540 & 880 & 1600 & 1835 & 0.82 & 0.38 & 6.2 & 0 \\
B & 1260 & 775 & 1580 & 2470 & 1.04 & 0.75 & 11.9 & 250 \\
E & 1290 & 760 & 1840 & 3540 & 1.43 & 0.99 & 17.7 & 540 \\
F & 1920 & 940 & 2195 & 3170 & 1.33 & 0.67 & 14.7 & 365
\end{tabular}


なお $\left(\vec{P}_{\mathrm{o}}\right)$ は重量分布について得られた重量分率 $50 \%$ を与光 る重合度の値である。

A-0 と A-2 では分布曲線の形が全く異なっているので詳しい 比較は無意味と考觉るが，いずれのパラメーターもA-2 の方が 小さい值を示し，明らかに分布が狭いといえるだろう。

一方, $60^{\circ} \mathrm{C}$ 温水湾溶出成分の低分子は無定形部分に存在 する確率が高く，また異種結合の多いことも考兄られるので，水 溶夜の紫外吸収スペクトルによる $230,280 \mathrm{~m} \mu$ K拈ける二重結 合， $p$ ーフェルヒドラジンによるカルボニル基（ヒドラゾンの $400 \mathrm{~m} \mu$ の吸収）を測定したが，A-0 にくらべ A-2 はいずれる 減少して㧊り，溶出部分には，これら異種結合が非常に多いこと を確認した。このように非常に容易な手段により，PVAの低分 子量で異種結合の多い成分を除去し，重合度分布をより均一にす ることができるが,このことは工業的にも意義のあることと思う。

\section{5 市販 PVA の重合度分布}

PVA 瀻維製造条件招よび性能に括よぼす原料 PVA の重合度 分布の影響は大さい。ここでは薄膜分別溶解法により,市販 PVA

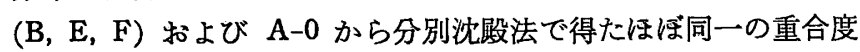
をむつ試料（A-1）の重合度分布曲線を求めた。 $\mathrm{B}$ の分別結果を 表 4 試料 B の分別抽出結果

\begin{tabular}{|c|c|c|c|c|c|}
\hline 区 分 & $\underset{(\%)}{\operatorname{AcOEt}}$ & $\underset{(\mathrm{g})}{\text { 抽出是 } w}$ & $\begin{array}{c}\text { 抽出分率 } \\
w_{i}(\%)\end{array}$ & $\begin{array}{l}\text { 軎稘重量分 } \\
\text { 率 } I(P)\end{array}$ & $\bar{P}$ \\
\hline 1 & 48 & 0.0407 & 2.74 & 0.014 & 120 \\
\hline 2 & 50 & 0.0382 & 2.57 & 0.040 & 235 \\
\hline 3 & 51 & 0.0379 & 2.55 & 0.066 & 320 \\
\hline 4 & 52 & 0.0425 & 2.86 & 0.093 & 390 \\
\hline 5 & 53 & 0.0545 & 3.69 & 0.126 & 500 \\
\hline 6 & 54 & 0.0654 & 4.40 & 0.166 & 560 \\
\hline 7 & 54.5 & 0.0724 & 4.87 & 0.213 & 655 \\
\hline 8 & 55 & 0.0770 & 5.18 & 0.263 & 770 \\
\hline 9 & 56 & 0.1876 & 12.61 & 0.352 & 960 \\
\hline 10 & 56.5 & 0.1230 & 8.27 & 0.456 & 1205 \\
\hline 11 & 57 & 0.1250 & 8.41 & 0.540 & 1390 \\
\hline 12 & 57.5 & 0.1350 & 9.09 & 0.627 & 1695 \\
\hline 13 & 58 & 0.1532 & 10.13 & 0.723 & 2050 \\
\hline 14 & 59 & 0.2100 & 14.11 & 0.844 & 2860 \\
\hline 15 & 100 & 0.1266 & 8.52 & 0.957 & 4720 \\
\hline
\end{tabular}

表4に例として示したが，これらの結果を Tung の方法でプロ ットしたのが, 図 12 でFを除いては全重合度領域にわたって 2 本以上の直線部分からなっている。得られた $a, b$ を表 5 火示し たが，この值から（2）式を用いて求めた分布曲線が図 13 であ る。この上うに，製品別にその分布状態は大きく異なって招り， 分布関数も複雑であるが，不均一性の表示を表 3 亿 A-0, A-2 と ともに示した。A-0 の分別区分である A-1 のUは 0.82 で mostprobable distribution の1飞比しわずか小さいにすぎなく， 分別沈殿で得られた分別区分が必ずしも狭い分布をもっていると はいえない。それにくらべ工業製品でもBのように3.3 項で述べ た理論曲線特よび低重合率 PVA 飞非常飞近い均一性の高い分布 をもっているものるあるのは興味深い。

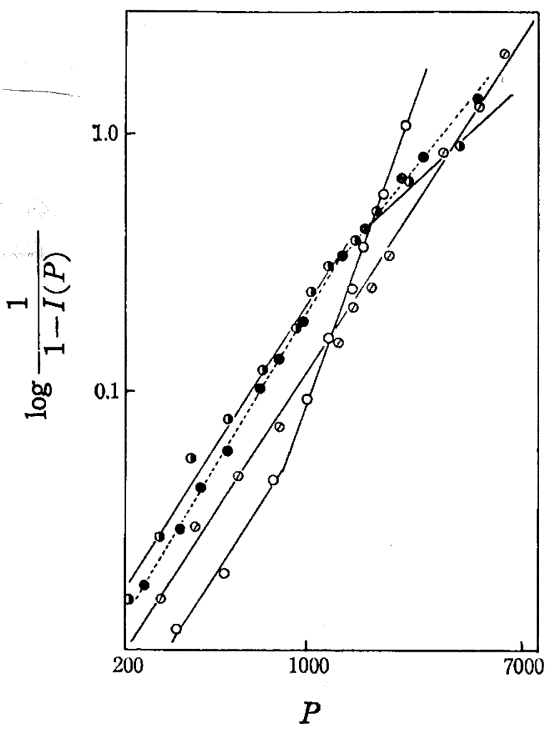

図 12 市股 PVA の分布の Tung 式によるプロット -O-:A-1, ----: B, -O-: E, -O-:F

表 5 Tung 式の $a, b$ 值

\begin{tabular}{|c|c|c|c|}
\hline 武 料 & 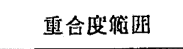 & $a$ & $b$ \\
\hline$A-0$ & 全 & $5.62 \times 10^{-4}$ & 1.02 \\
\hline \multirow{2}{*}{ A-1 } & $P<820$ & $3.35 \times 10^{-8}$ & 1.55 \\
\hline & $P>820$ & $8.76 \times 10^{-10}$ & 2.78 \\
\hline \multirow{3}{*}{ B } & $P<1400$ & $5.56 \times 10^{-8}$ & 1.64 \\
\hline & $P>1400$ & $1.38 \times 10^{-4}$ & 1.20 \\
\hline & $P<360$ & $1.89 \times 10^{-7}$ & 2.27 \\
\hline \multirow[t]{2}{*}{$\mathrm{E}$} & $360<P<1900$ & $3.78 \times 10^{-5}$ & 1.37 \\
\hline & $P>1900$ & $3.04 \times 10^{-3}$ & 0.79 \\
\hline F & 金 & $6.75 \times 10^{-8}$ & 1.53 \\
\hline
\end{tabular}

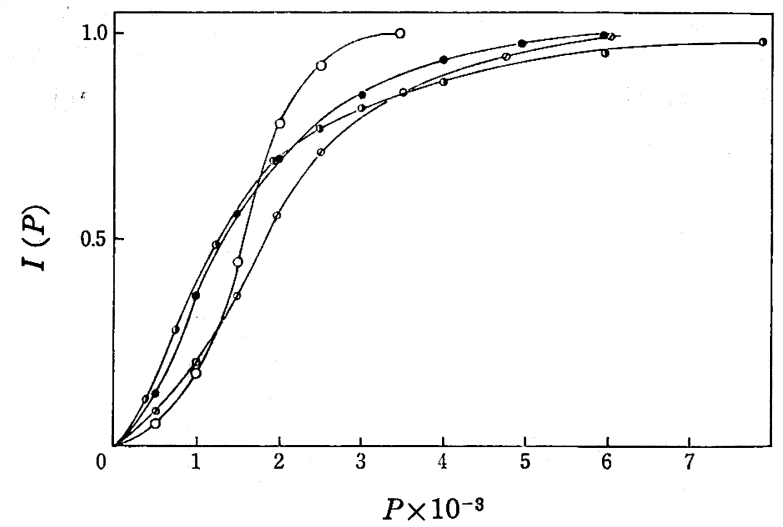

図 13 市肘 PVA の積分分布曲線

$-O-: A-1,-O-: B,-O-: E,-\bigcirc-: F$

工業製品に対する分布の幅を示す值を表 3 にすでに示したが, それぞれの平均重合度がさ注ど異ならず，また分布関数の形もほ ぼ同一であるとみなされるこれら試料の分布の尺度間にはそれぞ れ平行関係があることがわかる。 